\title{
Electrocardiographic and Vectocardiographic Findings in Friedreich's Ataxia
}

\author{
S. MALO, Y. LATOUR, M. COTE, G. GEOFFROY, \\ B. LEMIEUX AND A. BARBEAU
}

SUMMARY: Electrocardiographic and vectocardiographic changes are frequent in Fricdrcich's ataxia. In one of 35 patients both tests were normal. The vectocardiogram is more explicit in demonstrating the severity of the $Q R S$ changes with a right ventricular hypertrophy pattern present in $60 \%$ of cases. Serial examination and ECG tracings are recommended to monitor the cardiomyopathy in this progressive nearological disorder, in order to detect the onset of congestive heart failure, significant tachyarrythmias, or obstractive cardiomypathy.

RÉSUMÉ: Des modifications électrocardiographiques et vectocardiographiques sont fréquentes dans l'ataxie de Friedreich. Un seal sur nos 35 patients étudiés montrait un ECG et un VCG normanx. Le vectocardiogramme est plas précis dans sa démonstration des anomalies QRS, avec un patron d'hypertrophie ventriculaire droit présent chez $60 \%$ des patients. Des examens cliniques, VCG è ECG périodiques sont recommandés afin de suivre l'évolution de la cardiomyopathie dans cette maladie neurologique progressive, afin de déceler le début de l'insuffisance cardiaque, une tachyarrythmie signifiative on une cardiomyopathie obstracive, et d'offrir an traitement de soutien.

From the Centre Hospitalier Universitaire de Sherbrooke; the Hôpital Hôtel-Dieu de Montréal; the Hôpital Ste-Justine de Montréal, and the Clinical Research Institute of Montreal.

Reprint requests for the complete supplement on Friedreich's ataxia to: Dr. André Barbeau, Clinical Research Institute of Montreal, 110 Pine Avenue West, Montreal, Quebec, Canada H2W IR7.

\section{INTRODUCTION}

Electrocardiographic abnormalities, first described by Rathery, Mollaret, and Sterne (1934) in association with Friedreich's ataxia, have been the subject of many reports.

In the first large series of ECG studies, Evans and Wright (1942) noted one case of complete heart block, and ST-T changes in approximately 30 percent of 38 patients. Boyer et al (1962), in the study of 31 ECG tracings, found major electrocardiographic abnormalities in more than half, with atrial flutter or fibrillation in three and prominent ST-T changes in 16. In the most thorough evaluation of the cardiopulmonary involvement in Friedreich's ataxia, Thoren (1964) observed ECG changes in more than $90 \%$ of 49 tracings recorded at rest: sinus tachycardia in 17, atrial fibrillation or flutter in three, ventricular and supraventricular hypertrophy in eight, left ventricular hypertrophy in 10 , and minor or major ST-T changes in 41 . Only three patients had a normal ECG at rest. He concluded that the following ECG changes predominate in those patients most severely affected with Friedreich's ataxia: atrial tachyarrythmias, right-axis deviation, and right ventricular hypertrophy. In agreement with Evans (1942), he also noted similar ECG alterations in affected members of the same family.

Vectocardiographic (VCG) studies in the cardiomyopathy of Friedreich's ataxia have rarely been reported. Gregorini et al (1974), in the study of 10 cases, reported abnormal ECG findings in five of 10 patients but abnormal VCG patterns in all patients compatible with diffuse myocardial damage.

\section{CASE MATERIAL AND METHODS}

Thirty-five standard 12-lead electocardiograms and vectocardiograms of 36 patients with typical Friedreich's ataxia (Groups la and Ib) were available for analysis by two different observers. The vectocardiographic tracings were recorded by the Frank system using either a Hewlett-Packard 1520-A model recorder or computer derived, using the three orthogonal scalar leads $\mathrm{X}, \mathrm{Y}$ and $\mathrm{Z}$ recorded simultaneously with the ECG (Marquette Electronic Co.). The interpretations of ECG and VCG were in accordance with accepted norms for all age groups (Chew, 1967; Benchimol, 1973). When voltage criteria for different types $(A B C)$ of right ventricular hypertrophy were not present, the term "pattern" was used to describe the abnormal inscription of the QRS loop. Two such unusual patterns were seen with surprising frequencies, reflecting combinations of parts of the well described types $A B C$. We have called these patterns $\mathrm{A}+\mathrm{B}$ and $\mathrm{A}+$ C. Minor electrocardiographic ST-T changes were either flattened or biphasic $\mathrm{T}$ waves, major ST-T changes, negative $T$ waves with or without ST-segment depression or elevation.

\section{RESULTS AND DISCUSSION}

The results of our investigations are detailed in Table 1 and summarized in Table 2.

Sinus tachycardia was present in $20 \%$ of patients at rest. This finding 
TABLE 1

ECG and VCG in Friedreich's Ataxia: Detailed Results

\begin{tabular}{|c|c|c|c|c|c|}
\hline Group Ia & Electrocardiogram & Vectocardiogram & Group Ia & Electrocardiogram & Vectocardiogram \\
\hline 1 & $\begin{array}{l}\text { Minor ST-T changes } \\
\text { Vertical axia }\end{array}$ & $\begin{array}{l}\text { Increased anterior and } \\
\text { posterior vectors RVH } \\
B+C \text { (Figure I) }\end{array}$ & 18 & RVH & $\begin{array}{l}\text { Normal initial vector followed } \\
\text { by clockwise rotation of } \\
\text { QRS loop }\end{array}$ \\
\hline 2 & Right axis $220^{\circ} \mathrm{RVH}$ & $\begin{array}{l}\text { A QRS } 215^{\circ}-2.24 \mathrm{mV} \\
\text { Anti-clockwise rotation in } \\
\text { horizontal plane } \mathrm{RVH} \mathrm{A}+\mathrm{C}\end{array}$ & & & $\begin{array}{l}\text { Increased anterior forces } \\
\text { (1.86 } \mathrm{mV}-46^{\circ} \text { horizontal) } \\
\text { RVH A }+\mathrm{C}\end{array}$ \\
\hline \multirow[t]{2}{*}{3} & $\begin{array}{l}\text { Right axia } 165^{\circ} \\
R / s>1 \text { in } V_{1} \\
Q S V 5+V_{6}\end{array}$ & Severe RVH A $+C$ (Figure 2 ) & 19 & $\begin{array}{l}\text { Vertical axis } \\
\text { Diffuse minor ST-T changes }\end{array}$ & $\begin{array}{l}\text { Maximum QRS vector } 2.1 \mathrm{mV} \\
400^{\circ} \text { in horizontal plane } \\
\mathrm{RVH} B\end{array}$ \\
\hline & $\begin{array}{l}\text { Negative } T \text { precordial leads } \\
\text { RVH }\end{array}$ & & 20 & $\begin{array}{l}\text { Right axis } 115^{\circ} \\
\text { Normal }\end{array}$ & $\begin{array}{l}\text { Maximum A QRS: } 264^{\circ} \text { horizontal } \\
116^{\circ} \text { frontal }-1.8 \mathrm{mV} \text { right } \\
\text { posterior vector }\end{array}$ \\
\hline 4 & $\begin{array}{l}\text { RVH (probable) } \\
\text { Diffuse ST-T changes }\end{array}$ & $\begin{array}{l}\text { RVH B } \\
\text { Maximum QRS vector horizontal } \\
2.4 \mathrm{mV}-42^{\circ}\end{array}$ & 21 & $\begin{array}{l}\text { Right axis } 115^{\circ} \\
\mathrm{R} / \mathrm{s} \mid<1 \mathrm{~V} 5\end{array}$ & RVH C \\
\hline \multirow[t]{2}{*}{5} & $\begin{array}{l}\mathrm{R} / \mathrm{s}>1 \text { in } \mathrm{VI}_{\mathrm{I}} \\
\text { Major ST-T changes } \\
\mathrm{RVH}\end{array}$ & $\begin{array}{l}\text { RVH A } \\
\text { Clock wise rotation in horizontal } \\
\text { plane }\end{array}$ & & $\begin{array}{l}\text { RSR in VI }\left(R^{1} 10 \mathrm{mV}\right) \\
\text { Probable RVH }\end{array}$ & \\
\hline & & $1.08 \mathrm{mV} \cdot 59^{\circ}$ & 22 & $\begin{array}{l}\text { Documented transient } \\
\text { atrial flutter }\end{array}$ & Normal \\
\hline \multirow[t]{2}{*}{6} & $\begin{array}{l}\text { QRS axis } 200^{\circ} \\
\mathrm{R} / \mathrm{s}>1 \text { in } \mathrm{VI}\end{array}$ & $\begin{array}{l}\text { Increased anterior forces } \\
\text { Normal QRS rotation }\end{array}$ & & Normal & \\
\hline & $\begin{array}{l}\text { Minor ST-T changes } \\
\text { RVH }\end{array}$ & $\begin{array}{l}\text { Borderline criteria for } \\
\text { RVH B }\end{array}$ & 23 & $\begin{array}{l}\text { Right axis } 150^{\circ} \\
\text { Right atrial hypertrohy } \\
\text { RVH }\end{array}$ & $\begin{array}{l}\text { Normal initial vector with } \\
\text { terminal vector to the right } \\
\text { postero-superior }\end{array}$ \\
\hline \multirow[t]{2}{*}{7} & $\begin{array}{l}\text { PR } 0.10 \mathrm{sec} \\
\text { Negative } T \text { waves }\end{array}$ & $\begin{array}{l}\text { Normal QRS } \\
\text { Minor } T \text { loop anomaly }\end{array}$ & & & $\mathrm{RVH} A+\mathrm{C}$ \\
\hline & II-III and AVF & & 24 & Minor ST-T changes & $\begin{array}{l}\text { QRS nurmal } \\
\text { Major T loop changes }\end{array}$ \\
\hline 8 & $\begin{array}{l}\text { Right axis } 220^{\circ} \\
\text { RVH }\end{array}$ & $\begin{array}{l}\text { Terminal vector with right } \\
\text { posterosuperior axis } \\
\text { T loop at } 180^{\circ} \text { of } Q R S \\
\text { Borderline RVH C }\end{array}$ & 25 & $\begin{array}{l}\text { Major ST-T changes in } \\
\text { anterolateral precordial } \\
\text { leads }\end{array}$ & Major $\mathrm{T}$ loop anomaly \\
\hline 9 & $\begin{array}{l}\text { Minor ST-T changes in } \\
\text { anterolateral precordial }\end{array}$ & Minor $\mathrm{T}$ loop alteration & 26 & Normal & Normal \\
\hline \multirow[t]{2}{*}{10} & $\begin{array}{l}\text { leads } \\
\text { QRS axis }+90^{\circ} \\
R \text { in } V_{1} 7 \mathrm{mV} \text {. } V_{2} 22 \mathrm{mV}\end{array}$ & $\begin{array}{l}\text { Normal rotation } Q R S \\
\text { Increased anterior vector }\end{array}$ & 27 & $\begin{array}{l}\text { Right axis } 120^{\circ} \\
\text { RVH with ST-T change } \\
\text { (Figure 4) }\end{array}$ & RVH A + C (Figure 4) \\
\hline & RVH & $\begin{array}{l}1.53 \mathrm{mV} \text { at } 35^{\circ} \\
\mathrm{T} \text { loop abnormal } \\
\mathrm{RVH} \mathrm{B} \text { probable }\end{array}$ & 28 & $\begin{array}{l}\text { Right atrial hypertrophy } \\
\text { Left ventricular hyper- } \\
\text { trophy with ST-T changes }\end{array}$ & $\begin{array}{l}\text { T loop abnormal } \\
\text { QRS normal }\end{array}$ \\
\hline 11 & $\begin{array}{l}\mathrm{R} / \mathrm{s}=1 \text { in } \mathrm{VIV} 2 \\
\text { Diffuse minor } \\
\mathrm{ST}-\mathrm{T} \text { changes } \\
\text { Atrial fibrillation }\end{array}$ & RVH $A+C$ & 29 & $\begin{array}{l}\text { Vertical QRS axis } \\
\text { RVH (Figure 5) }\end{array}$ & RVH B (Figure 5) \\
\hline 12 & $\begin{array}{l}\text { Minor diffuse } \\
\text { ST-T changes }\end{array}$ & $\begin{array}{l}\text { Increased initial anterior } \\
\text { and terminal posterior forces } \\
\text { No voltage criteria } \\
\text { RVH B + C pattern }\end{array}$ & 30 & $\begin{array}{l}\text { Vertical QRS } \\
R \text { in Vi } 10 \mathrm{mV} \\
S \text { in Vs } 17 \mathrm{mV} \\
\text { RVH }\end{array}$ & RVH B $+C$ (Figure 6 ) \\
\hline \multirow[t]{2}{*}{13} & Major diffuse & Normal QRS loop & 31 & RVH (Figure 7) & RVH B $+C$ (Figure 7) \\
\hline & $\begin{array}{l}\text { "ischemic" T wave } \\
\text { abnormalities }\end{array}$ & $\mathrm{T}$ loop $180^{\circ}$ of "A" $\mathrm{QRS}$ & 32 & RVH (Figure 7) & RVH A (Figure 7) \\
\hline 14 & $\begin{array}{l}\text { Minor ST-T changes } \\
\text { Low voltage QRS in left } \\
\text { precordial leads } \\
\text { Prolonged Q-Tc } 0.44 \mathrm{sec} .\end{array}$ & $\begin{array}{l}\text { Microvoltage of QRS loop in } \\
\text { all planes } \\
\text { Normal rotation }\end{array}$ & 33 & $\begin{array}{l}\text { Right axis deviation } \\
\text { Incomplete right bundle- } \\
\text { branch block (Figure } 7 \text { ) }\end{array}$ & Normal (Figure 7) \\
\hline 15 & $\begin{array}{l}\text { Atrial flutter } \\
\text { Borderline low voltage } \\
\text { QRS } \\
\text { Minor ST-T changes }\end{array}$ & Normal & Group Ib $_{1}$ & Diffuse minor ST-T changes & $\begin{array}{l}\text { RVH B pattern but no } \\
\text { voltage criteria (Figure 3) }\end{array}$ \\
\hline 16 & $\longrightarrow$ & $\begin{array}{l}\text { Normal initial vector followed } \\
\text { by clockwise rotation of QRS } \\
\text { loop } \\
\text { T loop abnormal } \\
\text { RVH A }+C\end{array}$ & 2 & $\begin{array}{l}\text { Left atrial hypertrophy } \\
R+S>60 \mathrm{mV} \text { in } V_{3} \\
R \text { in } V_{3} 30 \mathrm{mV} \\
\text { Negative } T V_{4} \text { to } V_{6} \text {. } \\
\text { II, Ill, AVF } \\
\text { Biventricular hypertrophy }\end{array}$ & $\begin{array}{l}\text { RVH type B } \\
\text { Biventricular hypertrophy } \\
\text { probable (Figure 3) }\end{array}$ \\
\hline 17 & $\begin{array}{l}\text { Biventricular hypertrophy } \\
\text { with major ST-T changes }\end{array}$ & $\begin{array}{l}\text { Increased anterior and } \\
\text { right posterior vectors } \\
\text { Biventricular hypertrophy }\end{array}$ & 3 & $\begin{array}{l}\text { Major ST-T changes in ante- } \\
\text { rolateral precordial leads }\end{array}$ & $\begin{array}{l}\text { Left ventricular hypertrophy } \\
\text { with } T \text { loop changes (Figure } 3 \text { ) }\end{array}$ \\
\hline
\end{tabular}


TABLE 2

ECG and VCG Findings in Friedreich's Ataxia: Summary

Total number of cases

Sinus tachycardia

$(<100$ beats/min)

Atrial flutter/Fibrillation

Right ventricular hypertrophy

Left ventricular hypertrophy

Biventricular hypertrophy

ST-T changes Minor

Major

Right axis deviation

Normal

C.S. $31-5-73$

$1-M A B-4$

Figure I-VCG in horizontal plane showing RVH type $\dot{B}$ and $C$. Brother of Case 3, Group Ia.

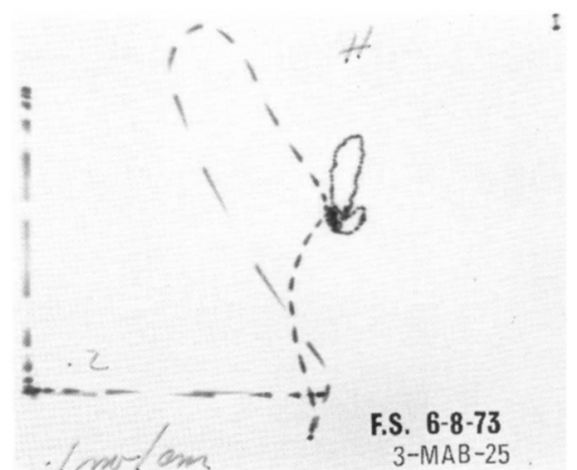

Figure 2-VCG in horizontal plane showing slightly atypical RVH type A and $C$ with initial anti-clockwise rotation of QRS loop during $250 \mathrm{msec}$. Sister of Case 1, Group la (Figure 1). ease.

$\begin{array}{cc}\text { ECG } & \text { VCG } \\ 35 & 35 \\ 7 & - \\ 2 & - \\ 15 & 23 \text { (total) }\end{array}$

TYPE: A:2

B:7
C:2
$\mathrm{A}+\mathrm{C}: 8$
$\mathrm{~B}+\mathrm{C}: 4$
1
2
3
3
-
3

has been reported by others, and Thoren (1964) also noted an abnormally high and rapid rise in heart rate in the standing position and during a light stress test. Various hypotheses have been proposed, including myocardial disease, decreased venous return, prolonged inactivity, abnormal oxygen transport or utilization, and disorders of the central neurovegetative tone.

Atrial flutter or fibrillation was observed in two patients and had been documented transiently in one other. All had severe neurological involvement including one who died during the course of the study. The incidence of supraventricular tachyarrythmias is much higher in the large necropsy studies of Friedreich's ataxia, increasing to $30 \%$ of cases (Boyer et al, 1962; Ivemark and Thoren, 1964; Hewer, 1968). The development of atrial flutter or fibrillation usually signifies, as with many cardiopathies, marked myocardial damage and clinical deterioration. Cardiogenic pulmonary and cerebral emboli and congestive heart failure are frequent terminal complications of this dis-

Frequently noted in previous studies, atrial or ventricular premature beats were not observed in our
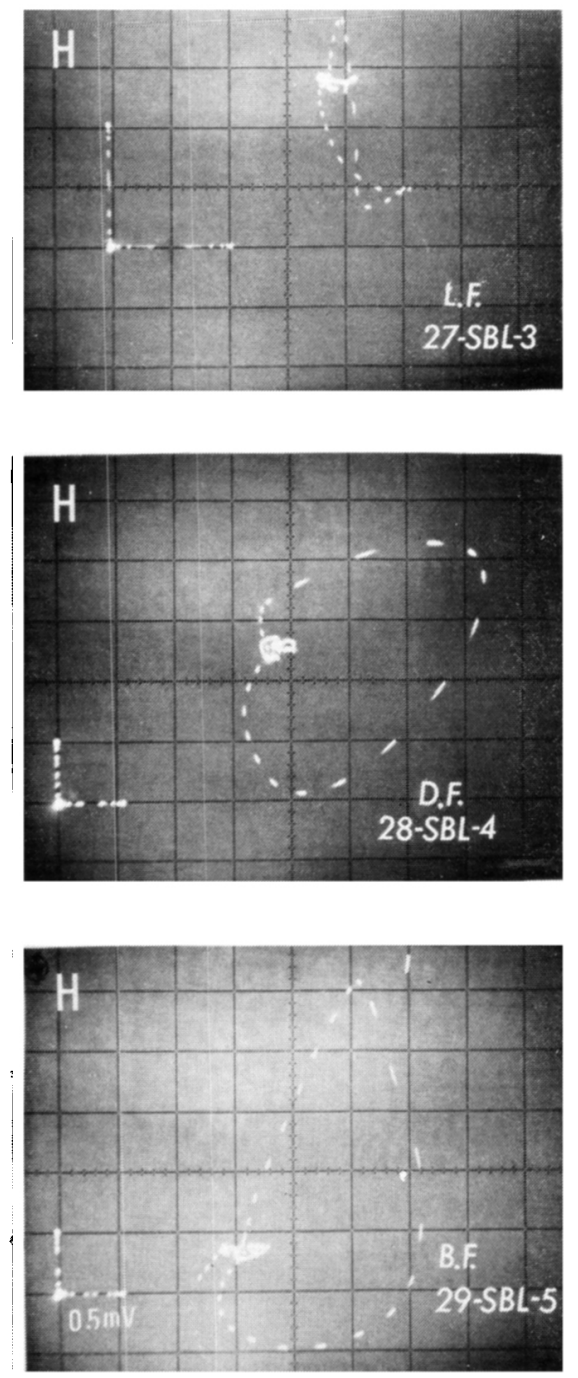

Figure 3-VCG in horizontal plane of three siblings of same family. L.F. showing RVH with atypical pattern of type B. D.F. showing classical RVH type $B$ and B.F. with left ventricular hypertrophy.

patients. Electrocardiographic and vectocardiographic signs of right ventricular hypertrophy were the most frequently observed abnormalities, present in 17 (ECG) and in 25 (VCG) of the 35 available tracings, including two with biventricular hypertrophy. This high incidence of RVH ( $60 \%$ of VCG) exceeds previous reports where left ventricular hypertrophy (LVH) was more frequent (Thoren, 1964) (Figures 1 to 7). In only one case was LVH noted (Figure 3).

In cardiomyopathies of other etiologies, atrioventricular and intraventricular conduction abnor- 

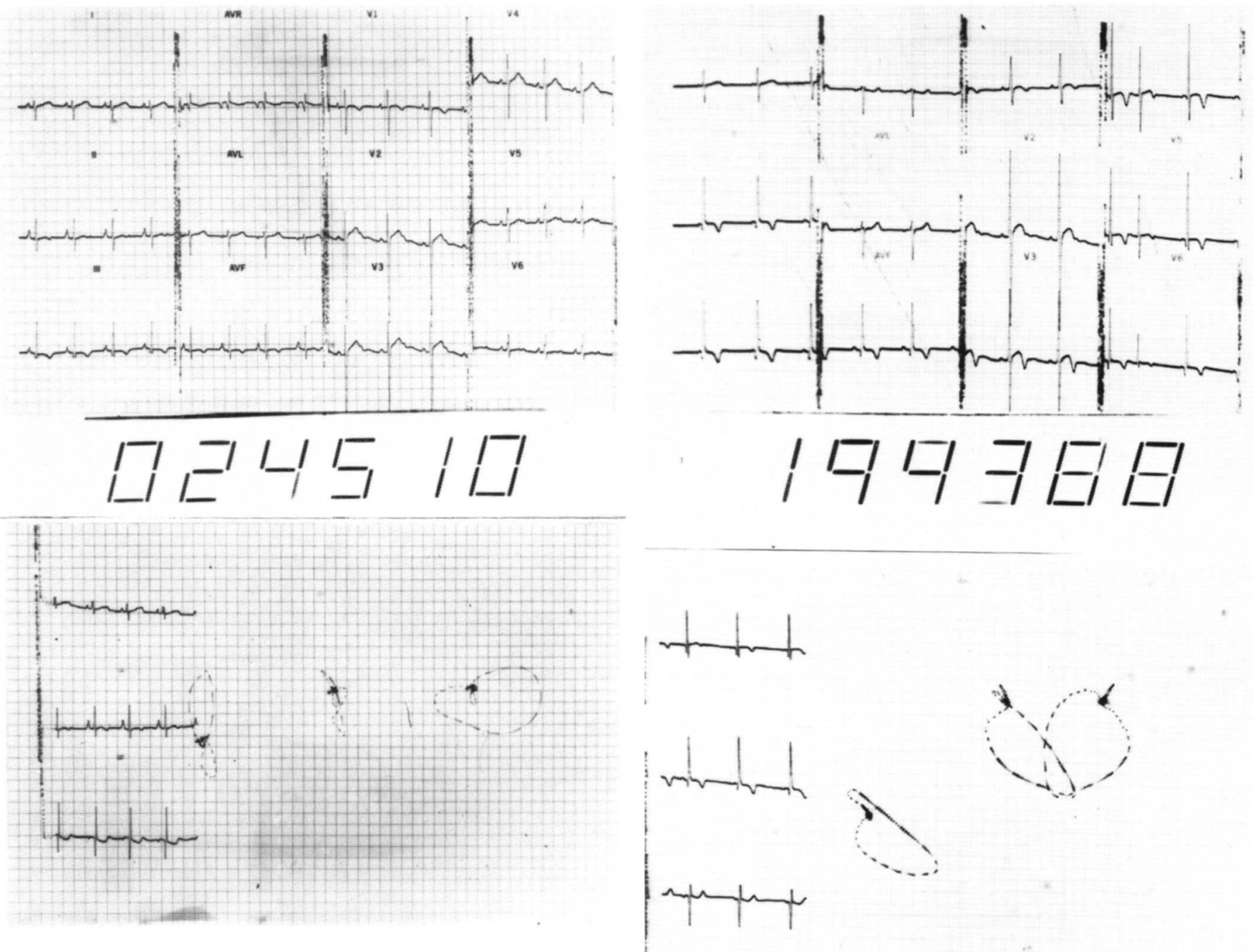

Figure 4-ECG and VCG of patient 27. Group Ia. Upper panel showing the ECG with right-axis deviation. right atrial hypertrophy and probable RVH. Lower panel. from left to right. horizontal, frontal, and left sagittal planes showing an initial clockwise rotation of the QRS vector and terminal posterior anti-clockwise rotation. $\mathrm{RVH} A+\mathrm{C}$ pattern.

Figure 5-ECG and VCG of patient 29. Group Ia. Upper panel showing the ECG, RVH with major ST-T changes. Lower panel showing, from left to right, horizontal, frontal, and sagittal planes. RVH type B. Brother of patient 30 . Group la (Figure 6). malities, pseudo infarct patterns, low voltage QRS, arrythmias, and left ventricular hypertrophy are frequent, but rarely right ventricular hypertrophy. RVH is usually associated with restrictive cardiomyopathies or subendocardial fibroelastosis, but infrequently with idiopathic hypertrophic cardiomyopathies, and then only with significant right outflow tract obstruction (Bahl and Massie, 1972). In two (cases 4 and 30, Group la) of our 13 cases studied hemodynamically significant left ventricular outflow tract obstruction was documented at rest $(78 \mathrm{mmHg}$ and $60 \mathrm{mmHg}$ ), but both had ECG and VCG compatible with RVH (Figure 6). In one case (Case 23, Group Ia) a discrete (13 $\mathrm{mmHg}$ ) right intraventricular systolic gradient was observed. In other diseases with spinocerebellar degeneration and ataxia, such as Charcot-Marie or Roussy-Levy syndromes, significant ECG and VCG changes are not found. Therefore, ECG and VCG findings may be of some help in the differential diagnosis. However, similar ECG patterns of RVH have been described in Duchenne's pseudo-hypertrophic muscular dystrophy. Steinert's disease or myotonic dystrophy, on the other hand, is characterized by atrioventricular and intraventricular conduction defects (Perloff, 1972).

The pathophysiology of these severe ECG changes has yet to be elucidated, but all of the following probably contribute: diffuse myocardial fibrosis with intraventricular depolarization abnormalities and varying degrees of concentric and asymmetrical septal hypertrophy. The moderate to severe dorsal scoliosis frequently present may not be a significant factor (Shack, 1971). Anatomically, the right ventricle is usually normal or slightly hypertrophied. Minor and major ST-T changes and right-axis deviation were also noted as the sole abnormalities in 13 (ECG) and six 


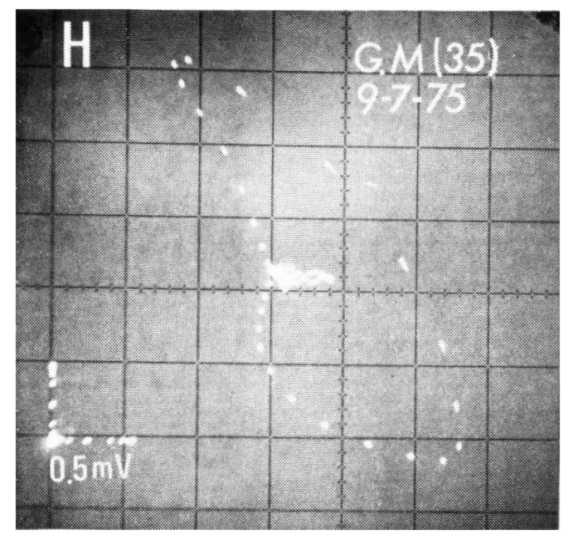

Figure 6-VCG in horizontal plane of patient 30. Group Ia. Increased initial left anterior and right posterior terminal vectors. RVH type B and C. Has documented left ventricular outflow tract obstructive with an intraventricular gradient of $60 \mathrm{mmHg}$. Brother of patient 29, Group la (Figure 5).
(VCG) patients (Figure 7). The abnormalities are not specific and are found in many cardiomyopathies. Four ECG and three VCG were normal, but in only one patient were both ECG and VCG normal.

In accordance with previous reports (Evans and Wright, 1942; Thoren, 1964), affected members of the same family did show similar but not identical ECG and VCG changes (Figure 1, 2, 5, 6, 7).

It has been suggested that some parallel exists between the severity of the neurological impairment and ECG abnormalities. We could not, however, document such a relationship. The ECG of the three patients with a slight handicap showed major ST- T changes in one, RVH in the second, and LVH in the third. On the other hand, the only patient with both normal ECG and VCG was severely incapacitated.

The time at which the ECG and VCG changes appear in this progressive neurological disease has not been determined. It is possible that they may precede significant neurological signs by many years, as demonstrated by the case described by Ruschhaupt et al (1972) with

Figure 7-ECG and VCG (in horizontal plane) of three siblings of same family. The ECG of D.T. and M.T. showing right-axis deviation with RVH and F.T., right-axis deviation and incomplete right bundle-branch block $\left(R^{1} 6 \mathrm{mV}\right)$. The VCG of D.T. showing RVH type B and C, of M.T., RVH type A, and of F.T. a slow inscription of the terminal vector.

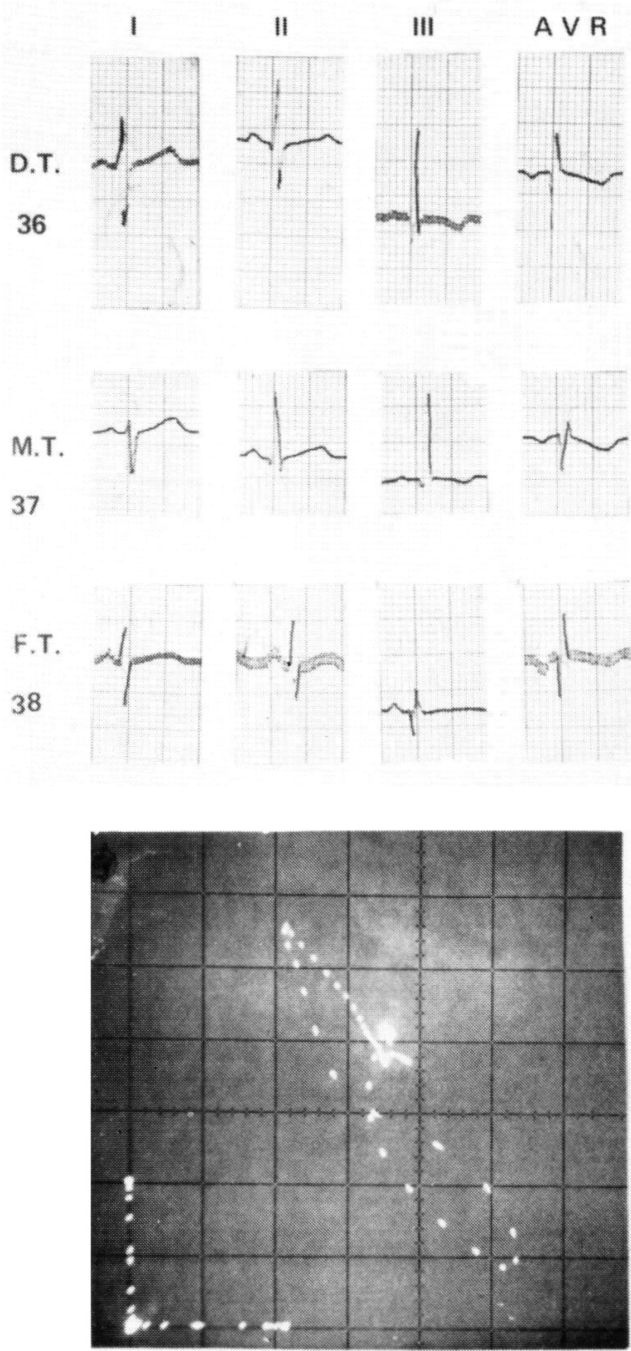

D.T. 36
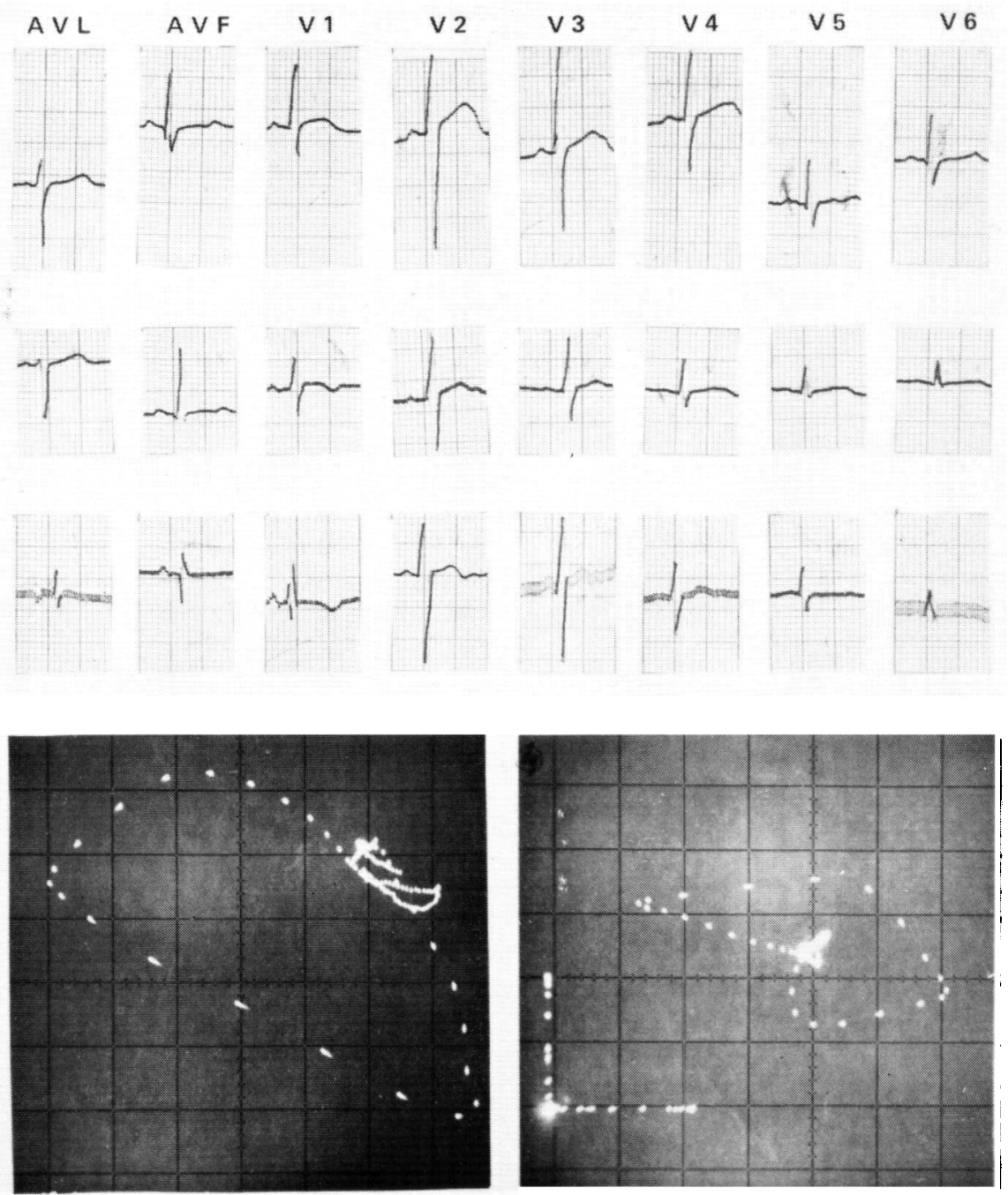

M.T. 37
F.T. 38 
symptomatic obstructive hypertrophic cardiomyopathy and initially few neurological signs or symptoms.

\section{ACKNOWLEDGMENTS}

The studies reported in this paper were supported in part by L'Association Canadienne de l'Ataxie de Friedreich. la Fondation Jeanne-Mance and the Medical Research Council of Canada.

\section{REFERENCES}

BAHL, O. P. and MASSIE, E. (1972). ECG and VCG patterns in cardiomyopathy. Cardiovascular Clinics, 4, 95-112 (No. 1).

BENCHIMOL, A. (1973). Vectocardiography. Williams and Wilkins Co.

BOYER, S. H., CHISHOLM, A. W. and McKUSICK, V. A. (1962). Cardiac aspects of Friedreich's ataxia. Circulation, 25, 493-505.

CHEW, T. and HELM, R. H. (1967). Clinical vectocardiography. Grune and Stratton. New York.

EVANS, W. and WRIGHT, G. (1942). The electrocardiogram in Friedreich's disease. Brit. Heart J., 4, 91-102.

GREGORINI, L., VALENTINI, R. and LIBIETTI, A. (1974). The vectocardiogram in Friedreich's ataxia. Amer. Heart J., 87, 158-163.

HEWER, R. L. (1968). Study of fatal cases in Friedreich's ataxia. Brit. Heart J., 31, 3-4l.

IVEMARK, B. and THOREN, C. (1964). The pathology of the heart in Friedreich's ataxia - Changes in coronary arteries and myocardium. Acta. Med. Scand., 175, 227-237.

PERLOFF, J. K. (1972). Cardiac involvement in heredo-familial neuromyopathic diseases. Cardiovascular Clinics, 4, 333-344.

RATHERY, P., MOLLARET, P. and STERNE, S. (1934). Un cas sporadique de maladie de Friedreich avec arythmie cardiaque et respiration de Cheyne-Stokes. Etude biologique et électrocardiographique. Bull. Mém. Soc. Méd. Hôp. Paris, 50, 1382.

RUSCHHAUPT. D. G., THILENUIS, O. G. and CASSELS, D. E. (1972). Friedreich's ataxia associated with idiopathic hypertrophic subaortic stenosis. Amer. Heart J., 84, 95-102.

SHACK, T. (1971). The VCG in adolescents and young adults with scoliosis. Vectocardiography 2. North Holland Publications.

THOREN, C. (1964). Cardiomyopathy in Friedreich's ataxia with studies of cardiovascular and respiratory function. Acta Paediat. (Stockholm), 53: suppl., 153. 